DOI: $10.19195 / 2084-5065.43 .14$

\title{
Kilka uwag o konstrukcji i konsekwencjach ciągu przestępstw w świetle nowelizacji kodeksu karnego z 20 lutego 2015 roku
}

\author{
RAJNHARDT KOKOT \\ Katedra Prawa Karnego Materialnego \\ Uniwersytet Wrocławski
}

Jedną z istotniejszych zmian, jakie wprowadził kodeks karny z 1997 r., było wydzielenie $\mathrm{z}$ dotychczasowej, jednolitej konstrukcji przestępstwa ciągłego (art. 58 k.k. z 1969 r.), wywołującej zarówno w doktrynie, jak i orzecznictwie liczne wątpliwości interpretacyjne, dwóch autonomicznych instytucji - czynu ciągłego, nawiązującego do jednoczynowej koncepcji przestępstwa ciągłego (art. 12 k.k.) oraz ciągu przestępstw opartego na jego koncepcji wieloczynowej (art. 91 $\S 1$ k.k. $)^{1} \mathrm{U}$ podłoża tej zmiany, wyrażającej się w odmiennym i zarazem odrębnym uregulowaniu obu form wielości zachowań objętych dotąd regulacją art. 58 k.k., legło przekonanie o nieefektywności dociekań na temat istoty przestępstwa ciągłego oraz nieskuteczności prób wskazania możliwie pewnych i stabilnych kryteriów wyznaczających jego ramy normatywne. Po kilku dekadach zmagań judykatury i dogmatyki prawa karnego z tą konstrukcją jasne się stało, iż istoty przestępstwa ciągłego w znaczeniu użytym w kodeksie karnym oraz znaczeniu,

1 Warto wspomnieć, że w toku dyskusji nad nowym kształtem ciągłości zachowania sprawcy w nauce prawa karnego pojawił się także nurt sugerujący, by całkowicie zrezygnować z posługiwania się tą konstrukcją, ograniczając się do pozostawienia realnego zbiegu wraz z jego konsekwencjami w postaci kary łącznej. Kierunek taki, borykając się z analogicznymi problemami interpretacyjnymi, wybrały w latach 90 . minionego stulecia m.in. systemy niemiecki i szwajcarski. Por. P. Konieczniak, Przestępstwo ciagte, PiP 1996, z. 12, s. 61 n.; M. Dąbrowska-Kardas, P. Kardas, Czyn ciagly i ciag przestępstw w kodeksie karnym z 1997 r., [w:] Nowa kodyfikacja karna. Kodeks karny. Krótkie komentarze, Warszawa 1998, s. 24; T. Bojarski, Przestępstwo ciagłe, PiP 1995, z. 3, s. 42; P. Kardas, Przestępstwo ciagłe - czyn ciagty, pomijalny czy realny zbieg przestępstw?, PiP 1997, z. 4, s. 61 n.; T. Dukiet-Nagórska, Koncepcja ciagu przestępstw na gruncie obowiązującego stanu prawnego i projektu kodeksu karnego, [w:] Problemy odpowiedzialności karnej. Księga pamiątkowa ku czci prof. Kazimierza Buchaty, red. Z. Ćwiąkalski et al., Kraków 1994, s. 39. 
jakie pojęciu temu nadała praktyka wymiaru sprawiedliwości, nie da się sprowadzić do wspólnego mianownika². Jak stwierdzono wprost w uzasadnieniu nowej regulacji: „Różnorodność koncepcji teoretycznych i rozwiązań w praktyce stwarza stan niepewności i różnego traktowania sprawców takich samych czynów przestępczych"3. Konstatacja ta miała uzasadniać dychotomiczne, porządkujące dotychczasowy dorobek wykładniczy, nowe ujęcie wielości zachowań objętych znamieniem ciągłości. Przyjęty w kodeksie karnym z 1997 r. dualizm nie spełnił jednak wszystkich pokładanych w nim nadziei, w szczególności tych związanych z przekonaniem, iż odtąd jednoczynowy i wieloczynowy model przestępstwa ciągłego przestaną być względem siebie konkurencyjne, a staną się komplementarne ${ }^{4}$. Nowe rozwiązanie kodeksowe miało objąć swym zakresem wszystkie przypadki mieszczące się dotąd w konstrukcji przestępstwa ciągłego. W rzeczywistości, jak się okazało, poza zakresem regulacji art. 12 i 91 k.k. pozostała część stanów faktycznych objętych niegdyś formułą ciągłości z art. 58 k.k. z 1969 r., do których, w zależności od sytuacji, mogą znaleźć zastosowanie regulacje dotyczące realnego zbiegu przestępstw albo reguły wyłączania wielości ocen, prowadzące do przyjęcia konstrukcji czynów współukaranych ${ }^{5}$.

Wyodrębniony z przestępstwa ciągłego czyn ciągły opiera się na założeniu jedności czynu w sensie normatywnym, na który mogą się składać czyny w znaczeniu „,naturalnym”, określane w przepisie mianem „zachowań”, gdy są podejmowane w krótkich odstępach czasu (przesłanka przedmiotowa), w wykonaniu z góry powziętego zamiaru (przesłanka podmiotowa) ${ }^{6}$ i przy spełnieniu warunku tożsamości pokrzywdzonego w razie zamachu na dobra osobiste. Konstrukcję tę określa także jedna przesłanka negatywna - niewyrażona w przepisie wprost, dająca się jednak wyinterpretować z rozwiązań pokrewnych — jaką jest warunek braku wyroku skazującego, chociażby nieprawomocnego, przedzielającego wielość zachowań objętych formułą art. 12 k.k. Jak więc z tego wynika, w konstrukcji czynu ciągłego wykorzystane zostały kryteria przyjmowane w doktry-

2 P. Kardas [w:] Kodeks karny. Część ogólna. Komentarz, t. 1, red. A. Zoll, Warszawa 2007, s. 156-157. W doktrynie prawa karnego dało się jednak zauważyć znaczny sceptycyzm wobec skutków wprowadzonej zmiany, która nie tylko nie rozwiązała dotychczasowych problemów interpretacyjnych, lecz także stworzyła nowe pola wątpliwości doktryny i praktyki wymiaru sprawiedliwości. Por. K. Daszkiewicz, Nadzwyczajne obostrzenie kary, [w:] Nowa kodyfikacja karna. Kodeks karny. Krótkie komentarze, z. 7, Warszawa 1998, s. 82.

3 Nowe kodeksy karne - z 1997 r. z uzasadnieniami, Warszawa 1997, s. 124.

${ }^{4}$ Por. A. Marek, O fikcji jednoczynowości przestępstwa ciąglego i jej konsekwencjach raz jeszcze, Prok. i Pr. 2010, nr 1-2, s. 128.

5 P. Kardas, [w:] Kodeks karny. Część ogólna. Komentarz, t. I, s. 156.

6 Por. P. Kardas, Przestępstwo..., s. 52; W. Zalewski, Przestępstwo ciagłe de lege lata i de lege ferenda, Prok. i Pr. 2003, nr 4, s. 81. Przyjęcie czynu ciągłego nie jest więc uzależnione od spełnienia jakichkolwiek dalszych przesłanek związanych chociażby z miejscem lub sposobem zachowania się sprawcy. Por. wyrok SA w Łodzi z dnia 12 października 2000 r., II Aka 155/00, Prok. i Pr. 2001, nr 5, poz. 21. 
nie i judykaturze jeszcze pod rządami kodeksu karnego z 1969 r. przy określaniu przestępstwa ciągłego $\mathrm{z}$ art. 58, z oczywistych powodów jedynie w ograniczonym zakresie, odpowiadającym założeniom jego jednoczynowej konstrukcji. Elementy składowe czynu ciągłego mogą być zarówno „zachowaniami”, które realizują znamiona przestępstwa, jak i takimi, które z powodu mniejszego ładunku społecznej szkodliwości nie są przestępstwami, będąc jedynie wykroczeniami bądź też czynami nieprzestępnymi z powodu znikomego stopnia społecznej szkodliwości. Gdyby zaś zachowania te realizowały znamiona typu podstawowego, a ich skutki, potraktowane sumarycznie, odpowiadałyby znamionom typu kwalifikowanego, ten stanowiłby podstawę odpowiedzialności sprawcy. Nie ma przy tym znaczenia, czy są to działania, czy zaniechania, a nawet wielość będąca ich kombinacją. W tym kontekście, jak plastycznie istotę regulacji art. 12 k.k. oddał W. Zalewski, czyn ciągły jawi się jako narzędzie „do czynienia z ułomków całości” ${ }^{7}$. Tracą one tym sposobem nie tylko swą autonomię normatywną, lecz także „tożsamość czasową"8, tworząc nową jakość podlegającą prawnokarnej ocenie, traktowaną jako jedna, integralna i nierozerwalna całość. Regulacja ta dezaktualizuje jednocześnie kontrowersje dotyczące kryteriów jedności-wielości czynów. Te bowiem wprost wskazuje ustawa karna, czyniąc je kryteriami normatywnymi. $Z$ tej więc perspektywy regulacja art. $12 \mathrm{k} . \mathrm{k}$. to rodzaj ustawowej dyrektywy interpretacyjnej mającej rozstrzygać przypadki powtarzających się zachowań charakteryzujących się elementem ciągłości ${ }^{9}$.

O ile konstrukcja czynu ciągłego zakłada jedność (jednostkowość) czynu, o tyle ciąg przestępstw wyrasta z koncepcji wieloczynowego przestępstwa ciągłego. Świadczy o tym już samo usytuowanie art. 91 k.k. w rozdziale IX, poświęconym „Zbiegowi przestępstw oraz łączeniu kar i środków karnych”. W jego prawną istotę wpisana została wielość autonomicznych zachowań realizujących znamiona czynu zabronionego. Tym samym jest on postrzegany jako odmiana realnego, jednorodnego zbiegu przestępstw połączonych klamrą ciągłości, której nie towarzyszy jednak wymiar kar jednostkowych za poszczególne zbiegające się przestępstwa, a następnie wymiar kary łącznej, lecz której konsekwencją jest wymierzenie jednej kary na podstawie przepisu, którego znamiona każdy z czynów wyczerpuje, z możliwością jej obostrzenia do górnej granicy zagrożenia zwiększonej o połowę (art. $91 \S 1$ in fine $)^{10}$. Art. $91 \S 1$ k.k. jest więc rodzajem lex spe-

7 W. Zalewski, op. cit., s. 86.

8 Por. wyrok SN z dnia 15 listopada 2005 r., IV KK 258/05, OSNKW 2005, nr 4, poz. 35.

9 M. Dąbrowska-Kardas, P. Kardas, op. cit., s. 40-41.

10 Por. W. Wolter, Problem struktury tzw. przestepstwa ciagłego, PiP 1982, z. 1-2, s. 24-26; idem, Głos w dyskusji w sprawie przestepstwa ciagłego, PiP 1979, z. 2, s. 111; M. DąbrowskaKardas, P. Kardas, op. cit., s. 85; J. Giezek [w:] Prawo karne materialne. Część ogólna i szczególna, red. M. Bojarski, J. Giezek, Z. Sienkiewicz, Warszawa 2010, s. 279; A. Marek, Komentarz do kodeksu karnego. Część ogólna, Warszawa 1999, s. 257. W literaturze zwracano uwagę, iż wyprowadzenie poza przestrzeń realnego zbiegu przestępstw ich jednorodnej wielości prowadzi 
cialis w stosunku do art. 85 k.k., w związku z tym wykluczony jest przypadek krzyżowania się zakresów tych regulacji ${ }^{11}$.

Jak wynikało z art. $91 \S 1$ k.k. do chwili jego nowelizacji ustawą z 20 lutego 2015 r., ciąg przestępstw zachodził, gdy sprawca popełnił w podobny sposób w krótkich odstępach czasu dwa lub więcej przestępstw, zanim zapadł pierwszy wyrok, chociażby nieprawomocny, co do któregokolwiek z nich. Każde z przestępstw, stosując wnioskowanie a contrario, musiało być też popełnione w warunkach braku zamiaru „z góry powziętego”, albowiem taka treść strony podmiotowej realizowałaby już subiektywny element konstrukcji z art. 12 k.k., określającego przesłanki jedności czynu ciągłego ${ }^{12}$. Zamiar towarzyszący kolejnym czynom sprawcy musiał być więc zamiarem nowym, odrębnym i autonomicznym. Mógł to być „taki sam” zamiar, wielokrotnie odtwarzany, podejmowany sukcesywnie, ale w żadnym razie „ten sam"13. Wszystkie taksatywnie wymienione w przepisie warunki musiały być spełnione łącznie. Brak któregokolwiek z nich powodował przejście na konstrukcję realnego zbiegu z art. 85 k.k., chyba że, jak wspomniano, spełnione były jednocześnie przesłanki ciągłości czynu z art. $12 \mathrm{k} . \mathrm{k}$.

Skutkiem ciągu przestępstw w pierwotnym jego ujęciu był wymiar jednej kary „na podstawie przepisu, którego znamiona każde z tych przestępstw wyczerpuje". Przesłanka tożsamości przepisu, którego znamiona realizować miało każde z przestępstw składających się na ciąg, od samego początku wywoływała w nauce prawa karnego wątpliwości ${ }^{14}$. $\mathrm{Z}$ jednej strony była ona łączona z potrzebą

do nieusprawiedliwionego łagodzenia odpowiedzialności sprawcy. Sprzeciwiać się temu miała zwłaszcza przesłanka podobnego sposobu popełniania przestępstw składających się na ciąg, co wszakże wskazywało na konsekwencję sprawcy oraz rodzaj specjalizacji w procederze przestępczym. Por. A. Marek, Komentarz..., s. 220. J. Warylewski akceptuje traktowanie ciągu jako odmiany realnego zbiegu tylko i dopiero wówczas, gdy sprawca dopuszcza się ciągu przestępstw i co najmniej jednego innego przestępstwa lub też dwóch lub kilku ciągów. Pogląd ten zdaje się nadmiernie koncentrować na skutkach realnego zbiegu, nie zaś na jego istocie, o której decyduje wszakże wielość przestępstw, niezależnie od ich charakteru. Por. J. Warylewski, Prawo karne. Część ogólna, Warszawa 2012, s. 386.

11 Por. M. Dąbrowska-Kardas, P. Kardas, op. cit., s. 83-84; uchwała SN z dnia 26 września 2002 r., I KZP 21/02, OSNKW 2002, nr 11-12, poz. 90.

12 Por. L. Gardocki, Prawo karne, Warszawa 2003, s. 148; także wyrok SN z dnia 1 kwietnia 2009 r., IV KK 372/08, niepublikowany.

13 Por. K. Daszkiewicz, Przestępstwo ciagłe i ciag przestępstw, Prok. i Pr. 1997, nr 11, s. 10.

14 Począwszy od tych, które wiązały się z zarzutem wadliwej redakcji art. $91 \S 1$ k.k., przyjmującego, iż „przestępstwo wyczerpuje znamiona przepisu”, gdy tymczasem znamiona te może wyczerpywać przecież jedynie czyn sprawcy, który dopiero wtedy staje się przestępstwem, rzecz jasna przy zaistnieniu pozostałych elementów struktury przestępstwa (A. Wąsek, Glosa do uchwały SN z 11 sierpnia 2000 r., I KZP 17/00, OSP 2001, nr 1, s. 20), poprzez te, iż znamiona są elementem typu czynu zabronionego, a nie przepisu, w którym zostały jedynie opisane, kończąc na sposobie rozumienia powyższej formuły ustawowej. Pełny wachlarz teoretycznie możliwych kierunków interpretacji omawianego sformułowania i ich ocenę przedstawił J. Majewski. Stosując gradację zakresów zastosowania tego przepisu — od najszerszego do najwęższego — wskazał następujące 
identycznego opisu podstawy skazania (kwalifikacji prawnej), bez względu zresztą na to, czy podstawę tę stanowił jeden przepis typizujący czyn zabroniony, czy też składało się na nią kilka przepisów występujących łącznie w ramach tożsamej kwalifikacji złożonej, co tym samym, rzecz jasna, wymuszało identyczną podstawę wyrokowania ${ }^{15}$. Z drugiej — wymóg tożsamości ograniczano, odnosząc go jedynie do przepisu stanowiącego podstawę wymiaru kary, sam więc opis podstawy skazania mógł się różnić. Za tym kierunkiem wykładni, najwłaściwszym z perspektywy zapewnienia możliwie szerokiego zakresu stosowania art. 91 § 1 k.k., przemawiać miały względy systemowe, funkcjonalne oraz kryminalnopolityczne, w tym potrzeba odnoszenia tej instytucji także do przestępstw kwalifikowanych nieidentycznie. Zasadność tego poglądu miał wzmacniać także charakter prawny ciągu przestępstw, który jest przecież instytucją związaną z karą i jej wymiarem, niemającą natomiast żadnego wpływu i znaczenia w procesie ustalania kwalifikacji podstawy skazania ${ }^{16}$. Niektórzy zwolennicy tego zapatrywania jego uzasadnienie wyprowadzali także wprost $\mathrm{z}$ ustawowej formuły przepisu, albowiem

możliwości: a) w kwalifikacji prawnej poszczególnych zbiegających się przestępstw (niekoniecznie jednakowej) miałby pokrywać się co najmniej jeden przepis, b) w kwalifikacji prawnej poszczególnych zbiegających się przestępstw (niekoniecznie jednakowej) pokrywałby się przepis, który stanowiłby podstawę wymiaru kary za każde przestępstwo, gdyby wymierzać za nie kary z osobna, c) kwalifikacja prawna poszczególnych zbiegających się przestępstw byłaby jednakowa (identyczna). J. Majewski, Glosa do uchwaty SN z dnia 11 sierpnia 2000 r., I KZP 17/00, Pal. 2001, z. 1-2, s. 242 n.; por. też M. Gajewski, Glosa do uchwaty SN z 11 sierpnia 2000 r., I KZP 17/00, OSP 2001, z. 9, s. 417; idem, W sprawie tożsamości kwalifikacji prawnej jako koniecznej przesłanki uznania, że przestęstwa zostały popetnione $w$ warunkach ciagu przestępstw, PS 2000, z. 11-12, s. 115 n.

15 Tak np. M. Dąbrowska-Kardas, P. Kardas, Czyn ciagty i ciag przestępstw. Komentarz do art. 12 i art. 91 k.k. z 1997 r., Kraków 1999, s. 92; J. Wojciechowski, Kodeks karny. Komentarz. Orzecznictwo, Warszawa 1998, s. 170; A. Marek, Komentarz..., s. 255; P. Kardas [w:] Kodeks karny. Część ogólna. Komentarz, s. 1011-1012; R.A. Stefański, Prawo karne materialne. Część ogólna, Warszawa 2008, s. 234; M. Gajewski, W sprawie tożsamości kwalifikacji prawnej jako koniecznej przesłanki i uznania, że przestępstwa zostaty popetnione w warunkach ciagu przestępstw, PS 2000, nr 11-12, s. 115 n.; J. Giezek [w:] Kodeks karny. Część ogólna. Komentarz, red. J. Giezek, N. Kłączyńska, G. Łabuda Warszawa 2012, s. 574; K. Daszkiewicz, Kary za przestępstwa ciagłe i ciagi przestęstw, Prok. i Pr. 2000, nr 5, s. 25; uchwała SN z dnia 11 sierpnia 2000, I KZP 17/00, OSNKW 2000, nr 7-8, poz. 56; wyrok SA w Lublinie z dnia 14 listopada 2001 r., II AKa 226/02, Prok. i Pr. 2004, nr 2, poz. 13; wyrok SA w Krakowie z dnia 4 lutego 2009 r., II AKa 3/09, KZS 2009, nr 2, poz. 33; wyrok SA w Olsztynie z dnia 7 sierpnia 2013 r., VII Ka 657/13, Legalis. Wspomniana zasada nie oznacza, oczywiście, na co zwraca uwagę M. Gajewski, iż podstawa wymiaru kary jest zawsze identyczna z podstawą skazania (np. skazanie z art. 177 § 1 k.k. w zw. z art. 177 § 2 k.k. — podstawa wymiaru kary — art. 177 § 2 k.k.). Por. M. Gajewski, Glosa do uchwały..., s. 417. Tam jednak, gdzie występują identyczne podstawy skazania, identyczne muszą też być podstawy wymiaru kary.

16 Por. J. Majewski, op. cit., s. 242 n.; idem, Kodeks karny. Komentarz do zmian 2015, Warszawa 2015, s. 343; por. także M. Gałązka [w:] A. Grześkowiak, K. Wiak, Kodeks karny. Komentarz, Warszawa 2014, s. 448; J. Lachowski, Glosa do uchwaty SN z 11 sierpnia 2000 r., I KZP 17/00, Mon. Praw. 2001, nr 16, s. 845-846; wyrok SN z dnia 24 listopada 2005 r., WA 32/05, OSNKW 2006, nr 1, poz. 1 . 
skoro stanowi on, że „sąd orzeka jedną karę na podstawie przepisu”, jest to jasne wskazanie, iż chodzi o tożsamy przepis, „wyczerpywany” przez przepis będący podstawą wymiaru kary ${ }^{17}$. Zarówno w piśmiennictwie, jak i w wypowiedziach judykatury przeważał jednak pierwszy z poglądów — zakładający identyczność podstawy skazania. Siłą rzeczy, w konsekwencji przyjęcia takiego założenia, tożsama musiała być jednocześnie także podstawa wymiaru kary. Inny układ w takiej sytuacji był bowiem niemożliwy. Tożsamość podstawy wymiaru kary była jednak w tym przypadku jedynie koniecznym następstwem wąskiego rozumienia spornej przesłanki, nie zaś punktem wyjścia wykładni, która znacznie rozszerzałaby zakres omawianej instytucji.

Wymóg tożsamości kwalifikacji prawnej rodził wątpliwości w wypadku zbiegu w warunkach ciągu przestępstw czynów o prostej i złożonej kwalifikacji prawnej $^{18}$. Powstawały one m.in. w sytuacji wielości przestępstw popełnionych w różnych formach stadialnych, które w każdej z form przeddokonania, w przeciwieństwie do postaci dokonanej, wymagają posłużenia się przepisem wskazującym na etap realizacji znamion (art. 16 k.k., art. 13 k.k.), czy też odmiennych postaci zjawiskowych czynów składających się na wielość przestępstw, które w formach niesprawczych, w przeciwieństwie do sprawstwa, zarówno wykonawczego, jak i niewykonawczego, muszą być dookreślone przez dodanie odpowiednio art. 18 $\S 2$ lub art. $18 \S 3$ k.k. Mimo bowiem, iż zachowania te są zrelacjonowane do konkretnego typu czynu zabronionego, to jednak mają inaczej określone zestawy znamion. Spór o możliwość objęcia ciągiem przestępstw różnych form stadialnych i zjawiskowych zdominował, jak się wydaje, dyskusję poświęconą omawianej przesłance, choć przypadki te nie były wszakże jedynymi budzącymi wątpliwości w kontekście wymogu tożsamości podstawy skazania. W tle omawianej przesłanki wątpliwa mogła być także multikwalifikacja zachowań objętych kumulatywnym zbiegiem przepisów ustawy z art. $11 \S 2$ k.k. czy też złożona kwalifikacja wynikająca z konieczności oddania w podstawie skazania dodatkowych okoliczności charakteryzujących sprawcę bądź jego zachowanie, które jednak nie doty-

17 Tak S. Żółtek [w:] Kodeks karny. Część ogólna, t. II, red. M. Królikowski, R. Zawłocki, Warszawa 2011, s. 781-782. Z tym „redakcyjnym” argumentem trudno jednak się zgodzić, albowiem buduje on uzasadnienie tego stanowiska na podstawie wyrwanego z kontekstu fragmentu przepisu, pomijając dalszą jego formułę tekstową. Artykuł $91 \S 1$ k.k. nie stanowi o przepisie, na podstawie którego wymierza się karę, lecz o ,przepisie, którego znamiona każde z tych przestępstw wyczerpuje", co w warstwie brzmieniowej zdaje się bardziej nawiązywać do podstawy skazania niż podstawy wymiaru kary.

18 Wątpliwości nie wywoływała natomiast sytuacja, gdy wszystkie przestępstwa objęte były kwalifikacją złożoną (np. w zw. z art. 11 § 2 k.k. lub art. 12 k.k.), choć wąska wykładnia zwrotu ,na podstawie przepisu" zawartego w art. $91 \S 1$ k.k., sugerującego liczbę pojedynczą w odniesieniu do podstawy skazania, mogła prowadzić do odmiennych wniosków. W pełni należy zatem zgodzić się z poglądem, iż zwrot ten powinno się traktować jedynie jako rodzaj skrótu językowego. Por. M. Dąbrowska-Kardas, P. Kardas, Czyn ciagły i ciag przestępstw w kodeksie..., s. 92-93. 
czyły każdego z przestępstw popełnionych w zbiegu. Chodziło w tym przypadku zwłaszcza o ograniczoną w stopniu znacznym poczytalność (art. $31 \S 2$ k.k.), powrotność do przestępstwa (art. 64 § 1-2 k.k.) czy też przesłanki wynikające z art. $65 \S 1$ k.k. ${ }^{19}$ Mogły powstawać także wątpliwości co do objęcia ciągiem przestępstw kwalifikowanych w związku z art. 12 k.k. i bez takiego związku ${ }^{20}$, albowiem bezsporne było tylko to, że w ramach ciągu mogły się znaleźć przestępstwa kwalifikowane z tego samego przepisu części szczególnej, z których każde zostało popełnione w warunkach art. $12 \mathrm{k.k} .^{21}$

W literaturze i orzecznictwie dopuszczono możliwość stosowania konstrukcji ciągu przestępstw w odniesieniu do postaci stadialnych, wykluczając ją w odniesieniu do różnych form zjawiskowych. Uzasadnieniem takiego kierunku interpretacji było założenie, że usiłowanie nie tworzy odrębnego typu czynu zabronionego, będąc jedynie jego stadium na etapie przeddokonania, gdy tymczasem formy niesprawcze realizacji znamion czynu zabronionego to autonomiczne typy przestępstw. Mimo iż zrelacjonowane do konkretnego, tego samego typu czynu zabronionego, mają one zupełnie inaczej określony zestaw znamion opisujących sposób realizacji, ten zaś musi być przecież „,podobny”22. Stanowisko to spotkało

19 Wyrok SA w Katowicach z dnia 30 października 2008 r., II AKa 266/08, Legalis wykluczył możliwość przyjęcia ciągu, gdy w skład zbiegu przestępstw wchodziły przestępstwa kwalifikowane z art. 64 k.k. lub art. 65 k.k. oraz bez tych przepisów. Taki sam pogląd wyraża L. Tyszkiewicz, rozciągając jego zakres na przypadki przestępstw kwalifikowanych w zw. z art. 31 $\S 2$ k.k. i popełnionych w stanie pełnej poczytalności. L. Tyszkiewicz, Kodeks karny. Komentarz, t. 1. Art. 1-116, Gdańsk 2005, s. 708. Odmiennie w tej kwestii M. Kulik, Glosa do wyroku SA w Katowicach z 30 października 2008 r., II AKa 266/08, Legalis, który przyjmuje, iż kwestia powrotności do przestępstwa bądź okoliczności wymienionych w art. $65 \S 1$ k.k. to wyłącznie kwestia sądowego wymiaru kary, a nie kwalifikacji prawnej. Trudno się zgodzić z tym poglądem, skoro przepisy te muszą być wszakże umieszczone nie tylko w podstawie wymiaru kary, lecz także w podstawie skazania.

${ }^{20}$ Możliwość taką dopuszcza P. Kardas [w:] Kodeks karny. Część ogólna. Komentarz, s. 1014, 1026; por. M. Dąbrowska-Kardas, P. Kardas, Czyn ciagty i ciag przestępstw w kodeksie..., s. 94-95; wyrok SN z dnia 24 listopada 2005 r., WA 32/05, OSNKW 2006, nr 1, poz. 11; wyrok SA we Wrocławiu z dnia 29 listopada 2005 r., II AKa 297/05, OSA 2006, nr 5, poz. 27; tak też S. Żółtek, op. cit., s. 780, który jednak stoi na odmiennym niż P. Kardas stanowisku, iż wymóg tożsamości przepisu prawnego każdego z przestępstw pozostających w ciągu odnosi się nie do podstawy skazania, lecz wymiaru kary, a ta, niezależnie od tego, czy zachowanie jest kwalifikowane w zw. z art. 12 k.k., czy też bez takiego związku, jest zawsze tożsama. Odmiennie w kwestii omawianej złożonej kwalifikacji np. M. Gajewski, W sprawie..., s. 115 n.; R.A. Stefański, Przegląd uchwat Izby Karnej Sąu Najwyższego w zakresie prawa karnego materialnego, prawa karnego wykonawczego i prawa wykroczeń za 2000 r., WPP 2001, nr 1, s. 98; wyrok SA w Lublinie z dnia 19 kwietnia 2004 r., II AKa 75/04, KZS 2004, nr 12, poz. 56.

21 Por. M. Dąbrowska-Kardas, P. Kardas, Czyn ciagty i ciag przestępstw w kodeksie..., s. 92 93, 115; L. Tyszkiewicz, op. cit., s. 707; P. Kardas [w:] Kodeks karny. Część ogólna. Komentarz, s. 1012; por. też np. wyrok SN z dnia 24 listopada 2005 r., WA 32/05, KZS 2006, nr 2, poz. 13.

22 Por. A. Zoll, Problemy tzw. przestępstwa ciagłego w propozycjach projektu kodeksu karnego, PS 1994, nr 3, s. 62; idem [w:] K. Buchała, A. Zoll, Kodeks karny. Komentarz, t. I, Kraków 1998, 
się ze zrozumiałą krytyką. Ujawniany w nim relatywizm był w literaturze postrzegany jako przejaw niekonsekwencji oraz „wykładni kreatywnej” jego zwolenników za cenę utrzymania możliwie szerokiego zakresu stosowania niedoskonałej konstrukcji określonej w art. $91 \S 1$ k.k. Nie było bowiem wątpliwości, iż wymogu tożsamości, a więc identyczności kwalifikacji prawnej, nie spełniają nie tylko różne formy zjawiskowe, lecz także odmienne formy stadialne ${ }^{23}$. Przejście w toku interpretacji tej przesłanki ciągu na wyższy poziom ,,podobnego sposobu” zachowania sprawcy, który odnajdywano w formach stadialnych, a ewidentnie brakować go miało w formach zjawiskowych, było więc postrzegane jako rodzaj procedury ratunkowej racjonalizującej możliwie szerokie stosowanie tej regulacji. Nie można było jednak tracić z pola widzenia, jak trafnie podkreślał J. Majewski, ogólniejszej oczywistości, iż wymóg tożsamości kwalifikacji prawnej oraz podobieństwo sposobu popełnienia to przesłanki ciągłości przestępstw względem siebie całkowicie niezależne i pozostające w określonym układzie chronologicznym ${ }^{24}$.

Jak wynikało z pierwotnej formuły tego przepisu, na określony w nim wieloczynowy zbieg przestępstw musiały składać się przestępstwa popełnione w „podobny sposób". Przesłanka ta, na zasadzie logicznego wnioskowania, była spełniona oczywiście i tym bardziej wówczas, gdy sprawca działał w sposób identyczny. Ustalanie jej spełnienia, w układzie chronologicznym, musiało następować dopiero po stwierdzeniu wymogu tożsamości przepisu prawnego, którego znamiona wyczerpało każde z przestępstw, albowiem brak tego warunku czynił bezprzedmiotowym badanie analogicznego sposobu zachowania sprawcy ${ }^{25}$. Przesłanki podobieństwa z art. $91 \S 1$ k.k. w zasadzie nie można było utożsamiać z „podobieństwem przestępstw" w rozumieniu art. $115 \S 3$ k.k. Wyjątkiem było podobieństwo

s. 572; A. Marek, Komentarz..., s. 256-257; A. Michalska-Warias, Niektóre problemy przestępstwa ciagłego $i$ tzw. ciagu przestęsstw w rozumieniu art. 12 k.k. i art. 91 k.k., AUMCS XLVII, 2000, s. 218-219; S. Żółtek, op. cit., s. 783; uchwała SN z dnia 11 sierpnia 2000 r., I KZP 17/00, OSNKW 2000, nr 7-8, poz. 56 oraz glosy do tego orzeczenia: J. Lachowski, op. cit., s. 849 (aprobująca); A. Wąsek, op. cit., s. 19-20 (krytyczna); J. Majewski, op. cit., s. 245 (aprobująca co do tezy, krytyczna wobec uzasadnienia); R.A. Stefański, Przeglą..., s. 114-115; por. też uchwała SN z dnia 21 października 2003 r., I KZP 11/03, OSNKW 2003, nr 11-12, poz. 89; postanowienie SN z dnia 17 czerwca 2003 r., II KK 304/02, OSNwSK 2003, poz. 1302; wyrok SA w Białymstoku z dnia 2 września 1999 r., II AKa 133/99, OSA 2000, nr 1, poz. 3.

${ }^{23}$ Tak np. P. Kardas, dla którego kwalifikacja form stadialnych (złożona i prosta) stanowi analogiczny powód niespełnienia przesłanki tożsamości kwalifikacji, jak w wypadku postaci zjawiskowych. Zob. P. Kardas [w:] Kodeks karny. Część ogólna. Komentarz, s. 1015; M. DąbrowskaKardas, P. Kardas, Czyn ciagty i ciąg przestępstw. Komentarz..., s. 92; J. Majewski, Kodeks karny. Komentarz do zmian 2015, Warszawa 2015, s. 343; idem, Glosa..., s. 243; A. Wąsek, op. cit., s. 20; M. Gajewski, W sprawie..., s. 115 n.; idem, Glosa..., s. 417; taki też pogląd wyraził SA we Wrocławiu w wyroku z dnia 27 czerwca 2012 r., II AKa 184/12, Legalis, nie robiąc wszakże z niego użytku w fazie wyrokowania na podstawie art. $91 \S 1$ k.k.

24 J. Majewski, Glosa..., s. 246.

25 J. Lachowski, op. cit., s. 847-848. 
sposobu popełnienia wynikające z zastosowania przemocy lub groźby jej użycia, składających się na formułę przestępstwa podobnego ${ }^{26}$. Podobieństwo wynikające $\mathrm{z}$ art. $91 \S 1$ k.k. miało więc znacznie węższy charakter niż wynikające $\mathrm{z}$ art. 115 $\S 3$ k.k. Wymóg podobieństwa będącego elementem ciągu przestępstw oznaczał, że sprawca musi działać w warunkach analogicznego modus operandi. Podobieństwo w tym kontekście oznaczało zgodność określonych cech czynów sprawcy w układzie okoliczności faktycznych. Musiały to więc być zachowania podjęte w zbliżonych okolicznościach przedmiotowych, z użyciem takich samych lub podobnych narzędzi bądź technik czy też w analogicznej, powtarzającej się sytuacji. Wobec ogólnego ujęcia tej przesłanki ocenie pod kątem podobieństwa mogły też podlegać liczne inne okoliczności faktyczne, których całokształt musiał być poddany analizie sądowej, znajdując wyraz w rozstrzygnięciu ${ }^{27}$. Mimo wielokrotnej realizacji znamion tego samego typu czynu zabronionego przyjęcie ciągu, za sprawą tego warunku, mogło być wyłączone, jeśli znamiona typu nie zostały przez sprawcę zrealizowane w analogiczny sposób. Tożsamość kwalifikacji prawnej stanowiła warunek pierwotny i zarazem konieczny podobnego sposobu popełnienia, lecz nie warunek wystarczający. Podobieństwo w stosunku do wymogu tożsamej podstawy skazania było bowiem parametrem całkowicie autonomicznym ${ }^{28}$. Nie można więc było go domniemywać, a obowiązkiem sądu było wykazanie w toku „wnikliwej i szczegółowej analizy okoliczności popełnienia każdego z przypisanych oskarżonemu i kwalifikowanych z tożsamej kwalifikacji prawnej przestępstw", iż in conreto zachodzi ${ }^{29}$. Wówczas więc, gdy wprawdzie sprawca wyczerpał znamiona tego samego typu czynu zabronionego, jednak w innej spośród alternatywnie przewidzianych $\mathrm{w}$ dyspozycji form czasownikowych, przesłanka ta nie była spełniona. $Z$ tego samego powodu możliwość przyjęcia ciągu była wyłączona, pomimo wyczerpania znamion tego samego przepisu, gdy sprawca raz uczynił to w formie działania, innym razem — zaniechania. W wypadku więc przestępstw, których popełnienie może nastąpić w każdej z tych form, spełniony musiał być wymóg podobieństwa sposobu zachowania w ramach tych form realizacji znamion, albowiem z natury rzeczy wykluczone było podobieństwo między nimi ${ }^{30}$. W kontekście poczynionych uwag powszechnie i jako oczywista formułowana była konstatacja, iż w ramach ciągu przestępstw nie mogą pozostawać różne postaci zjawiskowe, których określony w ustawie sposób realizacji (art. 18 § 1-3 k.k.) wyklucza możliwość przyjęcia między nimi podobieństwa. Krytycznej ocenie ten uogólniony pogląd poddał J. Majewski, wykazując, iż podobieństwa

26 Por. K. Daszkiewicz, Przestęstwo ciagłe i ciag przestępstw, Prok. i Pr. 1997, nr 11, s. 12;

M. Dąbrowska-Kardas, P. Kardas, Czyn ciagty i ciąg przestępstw w kodeksie..., s. $101 \mathrm{n}$.

27 Por. np. wyrok SN z dnia 4 kwietnia 2003 r., II KK 207/02, niepublikowany.

28 W. Wróbel, A. Zoll, Polskie prawo karne. Część ogólna, Kraków 2010, s. 576.

29 Wyrok SN z dnia 4 kwietnia 2003 r., II KK 207/02, Legalis.

30 J. Lachowski, op. cit., s. 846. 
sposobu popełnienia między różnymi formami zjawiskowymi nie da się jednak en bloc kategorycznie wykluczyć. Ocena w tym zakresie wynika bowiem jedynie z akceptacji określonego dogmatycznego zapatrywania na ich istotę i wzajemne relacje, determinującego postrzeganie ich zakresów znaczeniowych ${ }^{31}$.

W kontekście tej przesłanki ciągu przestępstw powstała także wątpliwość, czy podobieństwo sposobu popełnienia przestępstwa dotyczyć ma jego cech konstytutywnych, a więc ustawowych znamion, czy też jedynie okoliczności, które nie zostały określone w dyspozycji przepisu. W nauce prawa karnego communis opinio przyjmowano, iż punktem odniesienia mają być okoliczności, które nie stanowią ustawowych znamion, a jedynie kształtują sferę zdarzeń faktycznych, albowiem jeśli sposób popełnienia czynu zabronionego wyznacza granice typu, będąc jego ustawowym znamieniem, podobieństwo wprost wynika z tożsamości kwalifikacji prawnej — z uwzględnieniem, rzecz jasna, występowania w dyspozycji przepisu znamion alternatywnych, charakteryzujących sposób zachowania się sprawcy. Wobec wymogu tożsamości kwalifikacji prawnej przesłanka podobnego sposobu popełnienia stanowiła więc dodatkowy element charakterystyki, co do zasady niewymieniany w ustawowym zestawie znamion. Tym samym popełnienie przestępstw w podobny sposób miało oznaczać popełnienie ich w okolicznościach, które występują w odniesieniu do każdego z nich i jednocześnie nie zostały uwzględnione w zestawie znamion danego typu czynu zabronionego ${ }^{32}$.

31 J. Majewski, Glosa..., s. 246-247. W tym kontekście należy podzielić pogląd autora, odwołujący się do starego akademickiego kazusu „stania na czatach” i wątpliwości interpretacyjnych, jakie budził on w doktrynie i orzecznictwie, iż pomocnictwo może być zrealizowane w podobny sposób do sprawstwa. Można też dodać, iż nic nie stoi na przeszkodzie, by przyjąć podobieństwo sposobu zachowania podżegania i pomocnictwa, jako że ocena in concreto, czy określoną (w sensie przedmiotowym podobną lub nawet taką samą) formę udziału w przestępstwie uznać za nakłanianie, czy ułatwianie innej osobie popełnienie przestępstwa, będzie ostatecznie zależała nie od sposobu zachowania, lecz od stanu świadomości realizującego niesprawczą formę popełnienia czynu zabronionego wobec treści strony podmiotowej. W zależności od tego identyczne od strony przedmiotowej zachowanie może być albo podżeganiem, albo pomocnictwem psychicznym. $\mathrm{Z}$ drugiej jednak strony warto zauważyć, iż także w ramach tej samej formy zjawiskowej nie można in genere zakładać każdoczesnej tożsamości czy nawet podobieństwa sposobu popełnienia. W wypadku sprawstwa nie sposób mówić o podobieństwie sposobu popełnienia przestępstwa, gdy uwzględni się wykonawcze i niewykonawcze formy jego realizacji. Uwaga ta jest w pełni aktualna także w odniesieniu do pomocnictwa ze względu na alternatywny sposób ustawowego określenia jego realizacji (np. dostarczenie narzędzi lub udzielanie rady, możliwość działania lub zaniechania). Wreszcie i sposoby nakłaniania mogą być różne, albowiem nie można założyć, iż podobne do siebie są wszystkie formy nakłaniania, skoro powszechnie przyjmuje się, iż podobieństwo należy łączyć nie z konstrukcją znamienia, lecz sposobem jego realizacji, chyba że sposób ten — na odpowiednim poziomie szczegółowości — został stypizowany w ustawie. Wydaje się jednak, iż znamię nakłaniania tego wymogu uszczegółowienia nie spełnia.

32 Por. M. Dąbrowska-Kardas, P. Kardas, Czyn ciagty i ciag przestępstw w kodeksie ..., s. 99; P. Kardas [w:] Kodeks karny. Część ogólna. Komentarz, s. 1016-1017; J. Lachowski, op. cit., s. 847848; por. także wyrok SA w Lublinie z dnia 26 listopada 2002 r., II AKa 245/02, KZS 2004, nr 3, poz. 30 . 
W przesłance podobieństwa sposobu popełnienia chodziło więc o rzeczywiste podobieństwo faktów, a nie tylko podobieństwo wynikające z ustawowej charakterystyki typu. Przykładowo, jedna kradzież z włamaniem (art. 279 § 1 k.k.) mogła być uznana za popełnioną w podobny sposób do innej kradzieży $\mathrm{z}$ włamaniem nie ze względu na sam fakt „włamania”, a więc pokonania przez sprawcę określonej przeszkody, lecz ze względu na sposób (okoliczności) realizacji tego znamienia ${ }^{33}$.

Spore zmiany w konstrukcji przesłanek ciągu przestępstw, a w konsekwencji także w zakresie jego stosowania, przyniosła nowelizacja kodeksu karnego z 20 lutego 2015 r. Z pewnością jej niezaprzeczalnym walorem jest to, iż zdezaktualizowała ona wiele ważkich, a zadawnionych sporów o charakterze doktrynalnym — z poważnymi konsekwencjami zwłaszcza dla zakresu stosowania tej instytucji — skazanych w minionym stanie prawnym na trwanie, które czyniły tę konstrukcję jedną z bardziej kontrowersyjnych i dyskusyjnych. Spory te, będąc atrakcyjną materią dla teoretyków prawa, nierzadko dezorientowały praktykę, wywołując jej zauważalne wahania, a w efekcie brak jednolitej linii orzeczniczej. Należy podkreślić, iż ogólny systemowy obraz konstrukcji ciągu, na który składa się m.in. wymóg odrębnego identyfikowania i wartościowania każdego z czynów spiętych klamrą czasową, został zachowany. Niezmienna pozostała też reguła wymiaru kary $^{34}$. Już na wstępie należy jednak odpowiedzieć na zasadnicze pytanie, czy $\mathrm{w}$ obecnym stanie prawnym powszechnie akceptowane poprzednio stwierdzenie, iż ciąg przestępstw stanowi odmianę realnego zbiegu przestępstw - albowiem musiał spełniać wszystkie przesłanki zbiegu realnego z art. 85 k.k., powtórzone w art. 91 k.k., zachowało aktualność. W art. 85 k.k. ustawodawca zrezygnował z ogólnego warunku nieprzedzielenia wyrokiem skazującym przestępstw wchodzących w skład zbiegu realnego. W znowelizowanym art. $91 \S 1$ k.k. warunek ten pozostał. Pomimo tej zmiany w literaturze zasadnie wskazuje się, iż art. 91 k.k. zachował charakter zbiegu realnego, w którym ujawniają się mocne związki przedmiotowo-podmiotowe pomiędzy poszczególnymi, połączonymi węzłem ciągłości, przestępstwami ${ }^{35}$. Zwraca się uwagę, iż zachowanie warunku nieprzedzielenia przestępstw składających się na ciąg chociażby nieprawomocnym wyrokiem podkreśla wręcz, na tle zbiegu określonego w art. 85 k.k., tę szczególną więź stanowiącą podstawę modyfikacji granic odpowiedzialności i wpływającą na wymiar

33 Idąc tym tropem, nie można więc mówić o podobieństwie, gdy sprawca jednym czynem „włamał się” do samochodu, wybijając szybę, innym - niszcząc zamek w drzwiach. Por. J. Lachowski, op. cit., s. 348. Konkretne stany faktyczne mogą jednak wywoływać znacznie większe trudności interpretacyjne, a ocena, czy sprawca czynów realizujących ten sam typ przestępstwa działał w sposób podobny, czy nie, obciążona jest znacznym ładunkiem uznaniowości.

34 P. Kardas [w:] Nowelizacja prawa karnego. Komentarz, red. W. Wróbel, Kraków 2015, s. $654-655$.

35 J. Giezek [w:] Prawo karne materialne. Czesść ogólna i szczególna, red. M. Bojarski, J. Giezek, Z. Sienkiewicz, Warszawa 2015, s. 268. 
kary za wielość przestępstw objętych ciągłością ${ }^{36}$. Oznacza to tym samym, iż nowelizacja z 2015 r. doprowadziła do swoistego pogłębienia dualizmu w konstrukcji realnego zbiegu przestępstw, w którym $\mathrm{w}$ aktualnym stanie prawnym można wyróżnić dwie postaci. Jedną z nich tworzy wielość przestępstw przedzielonych, drugą - wielość przestępstw nieprzydzielonych wyrokiem skazującym, spośród nich zaś tylko ta ostatnia, będąca „nieprzeciętym łańcuchem” przestępstw jednorodnych, może stanowić podstawę przyjęcia ciągu w rozumieniu art. 91 k.k. Jak słusznie na tle nowego stanu prawnego, w kontekście omawianej relacji, zauważa P. Kardas, mimo wprowadzonych zmian ciąg przestępstw w zestawieniu ze zbiegiem z art. 85 k.k. zachował też swój „,redukcyjny” charakter, wyprowadzany $\mathrm{z}$ jednej strony $\mathrm{z}$ utrzymania skutku w postaci eliminacji jednego $\mathrm{z}$ etapów wymiaru kary, jakim jest określenie kar jednostkowych za poszczególne przestępstwa pozostające w ciągu, z drugiej — ze zmniejszonej, co do zasady, surowości kary będącej jego następstwem. Właściwość tego rozwiązania, jako „mechanizmu redukcyjnego" w relacji do następstw realnego zbiegu przestępstw, w znowelizowanym stanie prawnym została wręcz podkreślona za sprawą wprowadzenia możliwości wymiaru kary łącznej pozbawienia wolności do 20 lat, a więc w granicach wyznaczonych regułą nadzwyczajnego obostrzenia z art. $38 \S 2$ k.k., a także nowych rozwiązań dotyczących wymiaru kary, w tym także kary wymierzanej za ciąg przestępstw (art. 37a k.k. i art. 37b k.k.) ${ }^{37}$

W konstrukcji ciągu przestępstw nastąpiła zamiana warunku ,podobnego sposobu popełnienia" kolejnych przestępstw na przesłankę wykorzystania w trakcie ich popełniania „takiej samej sposobności”38. Tym samym postulat podniesie-

36 P. Kardas [w:] Nowelizacja prawa..., s. 653.

37 P. Kardas [w:] System Prawa Karnego, t. 5. Nauka o karze. Sadowy wymiar kary, red. T. Kaczmarek, Warszawa 2015, s. 557; P. Kardas [w:] Nowelizacja prawa..., s. 654.

38 Warto wspomnieć, iż do omawianej przesłanki — w zróżnicowanym zresztą zakresowo i redakcyjnie ujęciu — odwoływały się także poprzednie próby nowelizacji konstrukcji czynu ciągłego i ciągu przestępstw w kodeksie karnym z 1997 r. Projekt prezydencki nowelizacji kodeksu karnego z dnia 20 grudnia 2001 r. (druk sejmowy nr 181) przewidywał skreślenie art. 91 k.k. i wprowadzenie w zmienionym art. 12 nowej formuły jednolitego przestępstwa ciągłego. Przepis ten brzmiał: „Odpowiada za przestępstwo ciągłe ten, kto dopuszcza się dwu lub więcej jednorodnych czynów, podjętych w krótkich odstępach czasu w wykonaniu tego samego zamiaru lub z wykorzystaniem takiej samej sposobności”. W analogicznym kierunku zmierzały zmiany zaproponowane w tym czasie także w projekcie obywatelskim (druk sejmowy nr 775), który pod pojęciem przestępstwa ciągłego rozumiał: „dwa lub więcej zachowań podjęte w stosunkowo krótkich odstępach czasu ze z góry podjętym zamiarem lub wykorzystaniem tej samej trwałej sposobności i skierowane przeciwko takiemu samemu dobru prawnemu (art. $113 \S 3$ projektu). Przesłanką tą posługiwał się także projekt kodeksu karnego z 18 maja 2007 r. (druk sejmowy nr 1756). Usuwał on art. 91 k.k., modyfikując jednocześnie art. 12 k.k. Brzmieniem nawiązywał do poprzedniego projektu, różniąc się od niego jedynie detalami: „Odpowiada za przestępstwo ciągłe ten, kto dopuszcza się dwóch lub więcej czynów skierowanych przeciwko takiemu samemu dobru, podjętych w krótkich odstępach czasu, w wykonaniu z góry powziętego zamiaru lub z wykorzystaniem takiej samej trwałej sposobności". 
nia tej okoliczności do „wyższej godności”, formułowany przez W. Woltera przed ponad trzydziestoma laty, jeszcze w toku sporu o naturę tzw. przestępstwa ciągłego ziścił się w ustawowej formule ciągłości odnoszonej do „zbioru-ciągu” przestępstw $^{39}$. „Taka sama sposobność” stała się więc kolejnym czynnikiem mającym różnicować „ciągłą wielość przestępstw” (art. 91 § 1 k.k.) i wielość przestępstw składających się na realny ich zbieg (art. 85 k.k.). Modyfikacja ta, zgodnie z intencjami projektodawcy wyrażonymi w uzasadnieniu, miała na celu poszerzenie zakresu stosowania tej instytucji. W znowelizowanym stanie prawnym ciągowi przestępstw musi więc towarzyszyć określony ciąg sytuacyjny, wykorzystany wielokrotnie przez sprawcę. W warstwie semantycznej pojęcie „sposobności” należy odczytywać jako okazję do czegoś, sprzyjające określonemu zachowaniu warunki, korzystny z perspektywy osiągnięcia celu splot okoliczności, warunki zwiększające szansę powodzenia określonego przedsięwzięcia. Nie chodzi przy tym tylko o „tę samą sposobność”, choć oczywiście jej wykorzystanie realizowało będzie z natury rzeczy omawianą przesłankę, lecz o „taką samą” sposobność, a więc o każdą identyczną okoliczność sprzyjającą popełnieniu przestępstwa, choćby była ona ulokowana w odmiennym wymiarze miejscowo-sytuacyjnym $i$ aktualizowała się sukcesywnie w kontekście kolejnych zachowań objętych formułą ciągłości ${ }^{40}$. Wobec wyraźnie sformułowanego wymogu ustawowego, określonego w art. 91 $\S 1$ k.k., przesłanki tej nie spełni zatem okoliczność jedynie podobna, zbliżona czy analogiczna do uprzednio już przez sprawcę wykorzystanej. Warto na marginesie zwrócić uwagę, iż wymóg wykorzystania „takiej samej”, a nie jedynie „tej samej” sposobności odbiega zakresowo od ujęcia znanej z art. 12 k.k., integrującej wielość zachowań w ramach czynu ciągłego, przesłanki „z góry powziętego zamiaru”. W tym wypadku musi być to bowiem tylko „ten sam”, a nie także „taki sam” zamiar, sukcesywnie powracający czy odtwarzany ${ }^{41}$. W tym kontekście warto też dodać, iż w przeciwieństwie do wyraźnie subiektywnego znamienia tożsamości zamiaru przesłanka wykorzystania takiej samej sposobności ma bezsprzecznie charakter obiektywny. Prima facie użycie słowa „wykorzystanie” mogłoby sugerować co innego, a mianowicie określone nastawienie psychiczne, zorientowanie się sprawcy na instrumentalne wyzyskanie sprzyjających okoliczności. Należy jednak zgodzić się z poglądem, iż dowodzenie spełnienia tej przesłanki nie wymaga wykazywania jakiegokolwiek szczególnego stanu świadomości i woli sprawcy zrobienia użytku z nadarzającej się sposobności ${ }^{42}$. W pełni zatem wystarczające

39 W. Wolter, op. cit., s. 26.

40 Por. P. Kardas [w:] Nowelizacja prawa..., s. 665; J. Majewski, Kodeks karny..., s. 342.

41 A. Zoll, Glosa do postanowienia SN z dnia 9 marca 2006 r., V KK 271/05, OSP 2007, nr 1, s. 6.

42 Por. P. Kardas [w:] P. Kardas, G. Łabuda, T. Razowski, Kodeks karny skarbowy. Komentarz, Warszawa 2012, s. 83. Analogiczny pogląd wyrażał K. Buchała w odniesieniu do przestępstwa ciągłego z art. 58 k.k. z 1969 r. K. Buchała, Prawo karne materialne, Warszawa 1989, s. 428. Zwracał jednocześnie uwagę na doniosłość tej przesłanki, podkreślając, iż „psychiczna więź znajdująca się 
jest stwierdzenie, iż okoliczność taka obiektywnie zaistniała, a sprawca zrobił z niej użytek.

W doktrynie zauważyć można różnicę w podejściu do kwestii punktu odniesienia wyzyskania sprzyjających okoliczności. Sporne jest to, czy wykorzystanie takiej samej sposobności ma się odnosić wyłącznie do okoliczności towarzyszących realizacji znamion ustawowych określonego typu, czy też może dotyczyć ich wprost, znajdując odzwierciedlenie w ich konstrukcji. Przeważać zdaje się zapatrywanie - analogicznie jak w wypadku interpretacji przednowelizacyjnego warunku ,podobnego sposobu” popełnienia czynu — iż przesłanka ta może odnosić się jedynie do okoliczności zewnętrznych, dodatkowych, a więc tych, które nie kształtują konstrukcji typu przestępstwa popełnionego w ramach ciągu. Nie mogą to więc być okoliczności składające się na jego ustawowe znamiona i tworzące ich normatywny obraz. W przeciwnym razie oznaczałoby to faktyczne pominięcie tej przesłanki w toku oceny pod kątem ciągłości lub w najlepszym razie daleko idącą jej marginalizację ${ }^{43}$. Ponadto, jak wywodzi J. Giezek, rodziłoby to konieczność przyjmowania tożsamej kwalifikacji prawnej dla każdego z tworzących ciąg czynów ${ }^{44}$.

Warto przypomnieć, iż przesłanka wykorzystania „nadarzającej się sposobności” była przyjmowana w doktrynie i orzecznictwie sądowym już pod rządami kodeksu z 1932 r. do dookreślenia — w tym czasie jeszcze pozaustawowego — pojęcia przestępstwa ciągłego. Na zasadzie sukcesji interpretacyjnej składała się następnie także na charakterystykę pojmowanego wieloczynowo przestępstwa ciągłego w rozumieniu art. 58 k.k. z 1969 r. ${ }^{45}$ Jak wskazywano wówczas w piśmiennictwie, przesłanka ta stanowiła rodzaj kompleksu określonych okoliczności zewnętrznych tworzących pewien kontekst sytuacyjny, w jakim realizowany jest każdy z czynów sprawcy, składających się na wielość zachowań. Sprawca musiał więc wykorzystać tę samą lub taką samą sytuację, lub identyczny bądź analogiczny układ stosunków. Jego źródłem mogła być zarówno określona sytuacja faktyczna, jak i prawna ${ }^{46}$. W katalogu warunków przyjęcia przestępstwa ciągłego obok przesłanki jednorodzajowości przestępstw skierowanych przeciwko takiemu

u podłoża wykorzystywania nadarzającej się trwałej sposobności oraz ta sytuacja przedmiotowa, która »tworzy« ciąg przestępstw są decydujące z punktu widzenia kryminalnopolitycznego, mogą bowiem uzasadniać łagodniejsze traktowanie zbioru przestępstw”. K. Buchała [w:] K. Buchała et al., Komentarz do kodeksu karnego. Czesść ogólna, Warszawa 1990, s. 266.

43 P. Kardas [w:] Nowelizacja prawa..., s. 664.

44 J. Giezek [w:] Prawo karne materialne. Część ogólna i szczególna, s. 268. Przeciwny pogląd wyraża J. Majewski, nie dostrzegając ani językowych, ani pozajęzykowych argumentów uzasadniających zawężającą wykładnię omawianej przesłanki. Por. J. Majewski, Kodeks karny..., s. 342.

45 Por. np. A. Kaftal, Przestęstwo ciagłe w polskim prawie karnym, Warszawa 1985, s. 100 n.

46 Por. W. Świda, Prawo karne, Warszawa 1989, s. 209-210; K. Buchała, Prawo karne..., s. 428. 
samemu dobru prawnemu oraz tożsamości lub podobieństwa sposobu popełnienia okoliczność ta traktowana była jako alternatywa dla przesłanki „powziętego z góry zamiaru". Nic nie stało wszakże na przeszkodzie, by uwzględniać ją równolegle, a więc także wówczas, gdy towarzyszyła niewątpliwemu zamiarowi z góry powziętemu. Była wtedy dodatkowym czynnikiem spajającym wielość zachowań formułą ciągłości przestępstwa. Można zatem stwierdzić, iż pod rządami kodeksu karnego z 1969 r. stanowiła ona rodzaj minimum wskazującego na faktyczną więź między podejmowanymi przez sprawcę $\mathrm{w}$ warunkach ciągłości zachowaniami. W orzecznictwie sądowym pod rządami poprzednio obowiązującej kodyfikacji karnej, którego dorobek wykładniczy miał z reguły egzemplifikacyjny charakter, przesłanka ta była rozumiana jako specyficzna sytuacja, polegająca na wyzyskaniu pewnego powtarzającego się układu możliwości popełnienia czynu zabronionego. Na uwagę zasługuje, iż w praktyce orzeczniczej tego okresu dominował kierunek węższej jej interpretacji, przyjmujący, iż ma to być jedynie „ta sama”47 i to „trwała sposobność”, „trwała okazja powtarzania danego rodzaju czynów zabronionych", a więc stan utrzymujący się przez pewien czas, a nie jedynie sytuacja epizodyczna $^{48}$. Cecha ta mogła pozostawać w związku z wykonywanym zawodem, prowadzoną działalnością, pełnioną funkcją, zajmowanym stanowiskiem bądź jakąkolwiek inną powtarzającą się sytuacją, w której sprawca uzyskuje dostęp do określonego dobra prawnego i tę nadarzającą się sposobność cyklicznie wykorzystuje. Jako przykłady spełnienia omawianej przesłanki wskazywano m.in. wykorzystanie przy popełnieniu każdego z przestępstw niedostatecznego zabezpieczenia zgromadzonych w magazynie materiałów, przewóz określonego towaru, dostęp do kasy z pieniędzmi, wspólne zamieszkiwanie rodzeństwa pozostającego w związku kazirodczym itp. ${ }^{49}$ Stanu wykorzystania nadarzającej się sposobności nie warunkowała natomiast tożsamość pokrzywdzonego, choć sytuacja, gdy jego szczególne właściwości czy predyspozycje (np. łatwowierność, sytuacja osobista, rodzinna czy stan zdrowia) byłyby czynnikiem stymulującym sprawcę do popełniania kolejnych przestępstw, niewątpliwie stwarzałaby podstawę przyjęcia realizacji tej przesłanki. Pod rządami kodeksu z 1969 r. w piśmiennictwie zary-

47 Wyrok SN z dnia 19 listopada 1981 r., II KR 284/81, OSNKW 1982, nr 4-5, poz. 19.

48 Tak np. uchwała SN z dnia 8 kwietnia 1966 r., VI KO 42/62, OSNKW 1966, nr 7, poz. 69; uchwała SN z dnia 30 listopada 1972 r., VI KZP 44/72, OSNKW 1973, nr 2-3, poz. 20; wyrok SN z dnia 8 grudnia 1977 r., II KR 276/77, OSNKW 1978, nr 2-3, poz. 37; wyrok SN z dnia 8 lutego 1973 r., III KR 244/72, OSNKW 1973, Nr 9, poz. 109; wyrok SN z dnia 21 stycznia 1974 r., III KR 356/73, OSNKW 1975, nr 10-11, poz. 148; uchwała SN z dnia 11 marca 1988 r., VI KZP 49/87, OSNKW 1988, nr 5-6, poz. 32; por. K. Mioduski [w:] J. Bafia, K. Mioduski, M. Siewierski, Kodeks karny. Komentarz, Warszawa 1987, s. 232.

49 Tak np. wyrok SN z dnia 21 lutego 1972 r., I KR 277/71, OSNKW 1972, Nr 7-8, poz. 122; wyrok SN z dnia 21 stycznia 1974 r., III KR 356/73, OSNKW 1974, nr 5, poz. 92; wyrok SN z dnia 28 sierpnia 1978 r., I KR 171/78, OSNPG 1979, nr 4, poz. 58; por. W. Świda, op. cit., s. 209-210; K. Buchała [w:] K. Buchała et al., op. cit., s. 265. 
sował się spór o to, czy przesłanka ta ma stricte przedmiotowy charakter, czy też raczej należy ją dodatkowo łączyć z określonym antyspołecznym nastawieniem sprawcy. Dominowało wówczas stanowisko uzasadniane zwłaszcza względami kryminalnopolitycznymi, iż jej identyfikacja musi następować przy uwzględnieniu więzi elementów psychicznych, leżących u podłoża wykorzystania nadarzającej się trwałej sposobności, oraz sytuacji przedmiotowej, w której realizowane są poszczególne zachowania składające się na zbiór przestępstw ${ }^{50}$.

$\mathrm{Z}$ tego pobieżnego zestawienia wykładniczego dorobku nauki i judykatury w zakresie rozumienia przesłanki wykorzystania „nadarzającej się sposobności”, jako warunku przestępstwa ciągłego z art. 58 k.k. z 1969 r., wynika, iż obowiązujący jej normatywny odpowiednik jest ujęty i rozumiany bardziej liberalnie i w sposób mniej wymagający, zarówno w zakresie przyjmowanego uprzednio wymogu tożsamości, jak i trwałości czy choćby utrzymywania się tej okoliczności przez określony czas. Odmiennie też niż pod rządami poprzedniej regulacji, o czym wspomniano wcześniej, interpretowany jest również charakter tej przesłanki, albowiem w jej postrzeganiu akcentuje się raczej przedmiotowy aspekt odnoszący się do obiektywnie rozumianej „sposobności”, nie zaś specyficzne podmiotowe nastawienie sprawcy, wynikające z jej „wykorzystania”.

De lege lata od z górą dekady przesłanka wykorzystania takiej samej sposobności, w identycznej co przyjęta w art. $91 \S 1$ k.k. formule językowej, występuje także w konstrukcji art. $6 \S 2$ k.k.s., regulującego czyn ciągły, w którym stanowi alternatywną dla subiektywnego warunku „tego samego zamiaru” przesłankę przyjęcia ciągłości czynu. Jej wprowadzenie do kodeksu karnego skarbowego - które niewątpliwie znacznie rozszerzyło zakres stosowania konstrukcji czynu ciągłego na gruncie prawa karnego skarbowego, w tym rozciągając jego moc prawną na czyny nieumyślne — nie spotkało się jednak z życzliwym przyjęciem doktryny, głównie za sprawą rozbicia konstrukcji czynu ciągłego między prawem karnym powszechnym a prawem karnym skarbowym. Różnicowanie tożsamej konstrukcji prawnej na gruncie tych gałęzi prawa uznano za rozwiązanie niefortunne i niezasadne, choćby z perspektywy stosowania konstrukcji idealnego zbiegu przewidzianej w art. 8 k.k.s. ${ }^{51} \mathrm{~W}$ literaturze zauważa się, iż ustalenia doktryny i stanowisko odnośnie do tej przesłanki na gruncie kodeksu skarbowego w toku wykładni art. $91 \S 1$ k.k. powinny być wykorzystywane jedynie „,z odpowiednią ostrożnością", przy uwzględnieniu odmiennych charakterów czynu ciągłego opartego na koncepcji jednoczynowej i ciągu przestępstw wyrastającego z założeń koncepcji wieloczynowej i odmiennych funkcji, które obie konstrukcje pełnią.

${ }^{50}$ K. Buchała [w:] K. Buchała et al., op. cit., s. 266 oraz literatura tam przytoczona.

51 Por. T. Grzegorczyk, O niektórych zmianach w materialnym prawie skarbowym w zwiazku z nowelizacją kodeksu karnego skarbowego z dnia 28 lipca 2005 r., Prok. i Pr. 2006, nr 3, s. 7 n.; A. Zoll, Glosa do postanowienia SN z dnia 9 marca 2006 r., V KK 271/05, OSP 2007, nr 1, s. 6 n.; P. Kardas, [w:] P. Kardas, G. Łabuda, T. Razowski, op. cit., s. 85-86. 
Korzystając $\mathrm{z}$ istniejącego $\mathrm{w}$ tym zakresie dorobku wykładniczego, nie można przeoczyć i tego, iż w konstrukcji art. 6 § 2 k.k.s. omawiana przesłanka nie stanowi warunku sine qua non jego zastosowania, lecz warunek alternatywny subiektywnej przesłanki „wykonania tego samego zamiaru"52. Idąc tym tropem, P. Kardas wskazuje, iż w tym stanie rzeczy za merytorycznie zasadniejsze uznać należałoby szersze odniesienia do dorobku literatury i orzecznictwa w zakresie interpretacji rozumianego wieloczynowo pojęcia przestępstwa ciągłego z art. 58 k.k. z 1969 r. ${ }^{53}$ W kontekście tego zapatrywania nie można jednak tracić z pola widzenia, aktualnego przecież także w tej sytuacji, poglądu o potrzebie jednakowej wykładni identycznych pojęć ustawowych, nawet jeśli odnoszą się one do odmiennych jakościowo konstrukcji prawnych, analogicznie jak w wypadku interpretacji przesłanki „krótkich odstępów czasu” wspólnej czynowi ciągłemu i ciągowi przestępstw. Racje podejścia interpretacyjnego, oparte na regułach wykładni gramatycznej, zdają się w obu przypadkach analogiczne i równie zasadne.

W znowelizowanym kształcie następstw ciągu przestępstw dotychczasowa ustawowo określona konieczność wymierzania kary na podstawie „przepisu, którego znamiona każde z tych przestępstw wyczerpuje" zastąpiona została warunkiem jej orzekania na podstawie „przepisu stanowiącego podstawę jej wymiaru dla każdego z tych przestępstw". Zasadnie zmiana ta przez część doktryny nie jest postrzegana jako rozwiązanie nowe, a jedynie korekta „ujednoznaczniająca redakcję art. $91 \S 1$ k.k." 54 Taki wszakże kierunek szerszej niż wiodąca wykładnia tego przepisu obecny był w doktrynie, jak wspomniano, także pod rządami dotychczasowego ujęcia konstrukcji ciągu przestępstw, choć znajdował się niewątpliwie w mniejszości. Nowa formuła omawianego przepisu kończy więc definitywnie spór o zakres jego stosowania, a z innej perspektywy zakres ten znacząco poszerza. Znowelizowane ujęcie omawianej przesłanki oznacza, iż kwalifikacja poszczególnych czynów tworzących ciąg w obowiązującym stanie prawnym musi być jedynie w części tożsama, nie musi być natomiast identyczna. Koniecznym i zarazem wystarczającym warunkiem zastosowania tego przepisu w tej niewątpliwie mniej restryktywnie ujętej formule ustawowej jest „taka sama” czy też raczej „ta sama” podstawa wymiaru kary. Na marginesie należy zwrócić uwagę, iż wprowadzona formuła wymogu tożsamości może wydać się od strony językowej trochę niefortunna, wywołując wrażenie potrzeby choćby hipotetycznego uprzedniego wymiaru kary z osobna dla „każdego z tych przestępstw”, a więc czegoś na podobieństwo procedury wymiaru kar jednostkowych, właściwej zbiegowi przestępstw w rozumieniu art. 85 k.k. Wykładnia tego sformułowania nie

52 Por. J. Majewski, Kodeks karny. Komentarz..., s. 341; P. Kardas [w:] Nowelizacja prawa karnego. Komentarz, s. 661.

53 P. Kardas [w:] Nowelizacja prawa karnego. Komentarz, s. 661.

54 J. Majewski, Kodeks karny. Komentarz..., s. 344; J. Lachowski, op. cit., s. 846; por. T. Bojarski [w:] Kodeks karny. Komentarz, red. T. Bojarski, Warszawa 2016, s. 268. 
może, rzecz jasna, pójść w inną stronę niż w kierunku interpretacji przez pryzmat wyjściowego zastrzeżenia: ,gdyby karę orzekać za każde z przestępstw wchodzących w skład ciągu z osobna". Zastąpienie wymogu tożsamości (identyczności) podstawy skazania warunkiem tożsamości (identyczności) podstawy wymiaru kary powoduje, iż w obecnym brzmieniu przepisu na ciąg przestępstw mogą się składać nie tylko czyny kwalifikowane z jednego i tego samego przepisu (tożsama kwalifikacja prosta) lub wprawdzie z kilku przepisów, ale objętych identyczną kwalifikacją złożoną (art. $11 \S 2$ k.k.), lecz także zachowania mające prostą oraz złożoną kwalifikację w warunkach zbiegu kumulatywnego, jeśli tylko podstawą wymiaru kary będzie ten sam przepis. Podstawa przypisania i wartościowania może być więc różna (prosta lub złożona), byle tylko podstawa wymiaru kary była taka sama. Jeśli więc, jak wprost wskazuje się w uzasadnieniu projektu, sprawca jednym czynem wyczerpał znamiona typu określone w przepisie $X$, innym zaś znamiona określone $\mathrm{w}$ przepisach $\mathrm{X}$ i Y w zw. z art. 11 § 2 k.k., a podstawą wymiaru kary, w związku z zasadą wyrażoną w art. $11 \S 3$ k.k., będzie przepis X, nie ma przeszkód do przyjęcia ciągu przestępstw ${ }^{55}$. Idąc tym tropem, należałoby dodać, iż przyjęcie ciągu jest możliwe także gdy jeden z czynów wyczerpał jednocześnie znamiona określone w przepisach $\mathrm{X}$ i Y, inny zaś w przepisach $\mathrm{X}$ i Z, o ile w obu tych przypadkach przepis wspólny $\mathrm{X}$ byłby podstawą wymiaru kary ${ }^{56}$, albowiem warunkami koniecznymi i zarazem wystarczającymi jest tylko tożsamość podstawy wymiaru kary oraz identyczność jednego z elementów podstawy skazania. W tych okolicznościach ciąg przestępstw jawi się zatem nie tylko, jak dotąd, jako zbieg jednorodny, lecz także zbieg różnorodny. Przyjęciu ciągu przestępstw w takiej sytuacji nie stałaby na przeszkodzie nawet odmienna strona podmiotowa (umyślność, nieumyślność) typów czynów zabronionych określonych w przepisach „dopełniających”, niestanowiących, zgodnie z formułą art. $11 \S 3$ k.k., podstawy wymiaru kary ${ }^{57}$.

Omawiana zmiana w istotny sposób modyfikuje zakres stosowania konstrukcji ciągu przestępstw. W obecnym stanie prawnym w skład ciągu mogą wchodzić

55 Por. J. Giezek [w:] Prawo karne materialne. Część ogólna i szczególna, s. 269; P. Kardas [w:] Nowelizacja prawa karnego. Komentarz, s. 653, 656-657. Sytuację taką można zilustrować następującą kwalifikacją czynów pozostających w ciągu: 1) art. 280 § 1 k.k. i art. 156 § 1 k.k. w zw. z art. $11 \S 2$ k.k., 2) art. $280 \S 1$ k.k.

56 W wypadku chociażby dwuczynowego ciągu pierwszy z czynów realizowałby znamiona art. $280 \S 1$ k.k. i art. $156 \S 1$ k.k. w zw. z art. 11 § 2 k.k., drugi zaś znamiona art. $280 \S 1$ k.k. i art. $157 \S 1$ k.k. w zw. z art. 11 § 2 k.k. Podstawą wymiaru kary w oparciu o zasadę z art. $11 \S 3$ k.k. byłby w obu przypadkach art. 280 k.k.

57 P. Kardas [w:] Nowelizacja prawa karnego. Komentarz, s. 659. Taką sytuację zobrazować można przykładową kwalifikacją czynów, z których jeden wyczerpał znamiona art. $280 \S 1$ k.k. i art. 155 k.k. w zw. z art. $11 \S 2$ k.k., drugi zaś znamiona art. $280 \S 1$ k.k. i art. 156 k.k. w zw. z art. $11 \S 2$ k.k. Tożsamą podstawą wymiaru kary będzie w tej sytuacji art. $280 \S 1$ k.k. 
przestępstwa stanowiące nie tylko różne formy stadialne ${ }^{58}$, co w nauce i orzecznictwie było także przed nowelizacją z 2015 r. niemal powszechnie akceptowane, lecz także różne postaci przestępnego współdziałania ${ }^{59}$ — niepodobne przecież do siebie w swej formie i istocie - jeśli tylko odnoszą się do tego samego typu czynu zabronionego i da się wobec sprawcy, podżegacza czy pomocnika stwierdzić ,wykorzystanie takiej samej sposobności”"60. W takich przypadkach nie ma wprawdzie identycznej podstawy skazania, ale jest tożsama podstawa wymiaru kary. Przepisem tym jest przepis części szczególnej lub ustawy pozakodeksowej, typizujący określone zachowanie, którego znamiona zostały w formie usiłowania (art. 14 § 1 k.k. — ,granice zagrożenia przewidzianego dla danego przestępstwa", i to niezależnie od tego, czy nastąpiło to w formie usiłowania udolnego, czy nieudolnego) lub w jednej z form sprawczych lub niesprawczych zrealizowane (art. $19 \S 1$ k.k. — ,granice zagrożenia przewidzianego za sprawstwo”), określające granice ustawowego wymiaru kary, zmodyfikowane na podstawie reguły nadzwyczajnego obostrzenia, wynikającej z art. $91 \S 1$ k.k. Z tego samego powodu w grę wchodzi także możliwość objęcia tym samym ciągiem jednocześnie form stadialnych i zjawiskowych (np. usiłowanie i podżeganie do tego samego typu czynu zabronionego) ${ }^{61}$. Wątpliwości mogą natomiast powstać w wypadku zbiegu różnych form stadialnych, gdy jedną z nich jest karalne przygotowanie. W związku z tym, iż ustawa w odniesieniu do tej formy przeddokonania nie przewiduje analogicznego ogólnego odesłania do przepisu typizującego czyn zabroniony, jak to ma miejsce w wypadku usiłowania (art. 14 § 1 k.k.), lecz posługuje się modelem autonomicznych ustawowych zagrożeń (sankcji) przewidzianych za przestępstwo przygotowane, warunek tożsamości przepisu stanowiącego podstawę wymiaru kary nie zostanie spełniony. Tym samym wykluczona jest możliwość przyjęcia

58 Na przykład dwa czyny kwalifikowane odpowiednio z: 1) art. 13 § lub 2 k.k. w zw. z art. 279 § 1 k.k. oraz 2) art. 279 § 1 k.k.

59 Przykładowo trzy czyny realizujące znamiona: 1) art. 18 § 2 k.k. w zw. z art. $279 \S 1$ k.k., 2) art. $18 \S 3$ k.k. w zw. z art. $279 \S 1$ k.k., 3) art. $279 \S 1$ k.k. Tożsamą podstawą wymiaru kary jest art. $279 \S 1$ k.k.

60 Analogiczny pogląd wyrażany był w orzecznictwie SN pod rządami kodeksu karnego z 1969 r. Okoliczność, że sprawca w jednym przypadku osobiście zrealizował znamiona zamachu na określone dobro prawne, w innych natomiast był podżegaczem lub pomocnikiem, nie stała na przeszkodzie uznania jego czynów za przestępstwo ciągłe. Por. uchwała SN z dnia 30 listopada 1972 r., VI KZP 44/72, OSNKW 1973, nr 2-3, poz. 20; wyrok SN z dnia 9 czerwca 1971 r., IV KR 46/71, OSNKW 1971, nr 12, poz. 192; wyrok SN z dnia 4 sierpnia 1975 r., Rw 351/75, OSNKW 1975, Nr 10-11, poz. 148. Więzi tej nie zrywał również fakt, iż sprawca kolejne czyny popełniał w zmienionej konfiguracji personalnej, współdziałając z różnymi osobami. Por. wyrok SN z dnia 15 czerwca 1978 r., II KR 119/78, OSNKW 1979, nr 1-2, poz. 79.

61 Odmiennie M. Gajewski, Glosa do uchwaty..., s. 417, który argumentuje, iż podstawą wymiaru kary za usiłowanie, w przeciwieństwie do dokonania, nie jest przepis części szczególnej, lecz art. 14 § 1 k.k. Por. też wyrok SA w Rzeszowie z dnia 19 września 1993 r., II AKr 80/93, OSA 1994, nr 3, poz. 17. 
konstrukcji ciągu przestępstw ${ }^{62}$. Niezmiennie natomiast niedopuszczalne jest przyjęcie ciągu, gdy poszczególne czyny realizują znamiona typu podstawowego oraz kwalifikowanego lub uprzywilejowanego. Przesłanka tożsamości przepisu stanowiącego podstawę wymiaru kary w takim przypadku nie może być spełniona. Jeśli na omawianą zmianę spojrzeć przez pryzmat dodanego nowelizacją znamienia „wykorzystania takiej samej sposobności”, jasne staje się, iż przesłanka ta może odnosić się nie tylko do okoliczności tworzącej kontekst sytuacyjny realizacji znamion przestępstwa stanowiącego podstawę wymiaru kary, lecz także do realizacji znamion przepisu dopełniającego kwalifikację podstawy skazania w ramach kumulatywnego zbiegu przepisów ustawy. Okoliczność ta, jak już zaznaczono, nie może wszakże stanowić znamion określonych w tych przepisach.

Nowelizacja kodeksu karnego z 20 lutego 2015 r., istotnie reformująca konstrukcję przesłanek ciągu przestępstw, znacząco zwiększając zakres przypadków objętych regulacją art. $91 \S 1$ k.k., w zakresie formuły, granic i dyrektyw wymiaru kary instytucję tę ominęła. W tym kontekście aktualny pozostaje obecny w doktrynie od bez mała dwu dekad spór o klasyfikację i ocenę prawnego charakteru tej reguły wymiaru kary i jej usytuowanie w przestrzeni zwyczajnego bądź też nadzwyczajnego wymiaru. Zgodnie z wypracowanym już uprzednio w doktrynie i orzecznictwie stanowiskiem kara za ciąg przestępstw jest wymierzana na ogólnych zasadach, przy uwzględnieniu dyrektyw określonych w art. 53 k.k. oraz dyrektyw szczególnych, adekwatnie do kategorii sprawcy i rodzaju stosowanej wobec niego kary. Niezmiennie konkretyzacja kary za ciąg na płaszczyźnie sądowego wymiaru następuje także na podstawie charakterystyki poszczególnych przestępstw, które go tworzą, oraz relacji między nimi. Upraszczając znacznie sprawę, należy jedynie przypomnieć, iż ścisła więź przedmiotowa (np. wynikająca ze znacznej bliskości czasowej) i podmiotowa (np. sukcesywnie odtwarzalny, choć nie podjęty z góry, zamiar) pomiędzy przestępstwami składającymi się na ciąg przestępstw, zbliżająca tę konstrukcję do instytucji czynu ciągłego oraz istnienie innych okoliczności scalających wielość czynów, w tym zwłaszcza identyczność kwalifikacji prawnej, uzasadnia wymiar kary w granicach ustawowego zagrożenia przewidzianego $\mathrm{w}$ przepisie stanowiącym wspólną podstawę wymiaru kary za każde z przestępstw pozostających w ciągu, na podobieństwo wymiaru kary za czyn ciągły. W tych natomiast przypadkach, w których zaznacza się autonomia poszczególnych przestępstw spiętych klamrą ciągłości (np. za sprawą kumulatywnej kwalifikacji części lub wszystkich czynów objętych ciągiem, przy spełnieniu. rzecz jasna. wymaganego ustawą warunku tożsamości przepisu stanowiącego podstawę wymiaru kary), a więź między nimi jest wyraźnie słabsza, aktualizowałaby się możliwość, a nawet potrzeba wyjścia ponad górną granicę zagrożenia, zgodnie z formułą wymiaru kary wynikającą z art. $91 \S 1$ k.k. i w nawiązaniu do

62 P. Kardas [w:] Nowelizacja prawa karnego. Komentarz, s. 658. 
surowości reguł wymiaru kary łącznej ${ }^{63}$. Analogicznie jak w dotychczasowym stanie prawnym unormowana została także kwestia wymiaru kary w warunkach wyroku łącznego za przestępstwa pozostające w ciągu. Zgodnie z regułą określoną $\mathrm{w}$ art. 91 § 3 k.k. jej wymiar powinien opierać się na szczególnej zasadzie określającej granice wymiaru kary za ciąg przestępstw oraz uwzględniać dyrektywy — ogólne i szczególne - sądowego wymiaru tej kary. Nie może natomiast odwoływać się do przewidzianej w art. 85a k.k. odnośnie do realnego zbiegu przestępstw nowej, szczególnej dyrektywy wymiaru kary łącznej, eksponującej w jednostkowym wymiarze kary potrzebę uwzględnienia przede wszystkim prewencji indywidualnej i generalnej. Oba przypadki mają wprawdzie wspólną cechę genus — wielość popełnionych przez sprawcę przestępstw, jednakże ich wyrazista autonomia wynikająca $\mathrm{z}$ ustawowych cech tworzących ich differentia specifica wyklucza możliwość stosowania tego przepisu nie tylko wprost, lecz także per analogiam.

\section{A few remarks about the structure and the consequences of the series of crimes in the light of the amendment to the Penal Code of February 20, 2015}

\section{Summary}

The article concerns the problem of the legal structure of the so-called series of crimes. The attention is concentrated on the changes in terms of evidence of this institution introduced by the amendment to the Penal Code of February 20, 2015. The previous statutory formula of Art. 91 $\S 1$ of the Penal Code was recalled, especially the annulled premise of the "similar way" of committing crimes bounded together in series, remembering at the same time the doubts and interpretative arguments which accompanied that interpretation. In the circle of interests remains also the issue of the statutory understanding of the requirement of identity of "the regulation whose criteria each of those crimes fully fulfill", which forms the basis for the punishment given for the series of crimes. The arguments of the ideas competing in this matter were also recalled as well as the effects that might have been caused while implementing such practice. Taking the above into consideration the modifications within the statutory formula of the series of crimes were discussed. A special attention was drawn to the new premise of "using the same opportunity" and the consequences that are caused by introducing this premise for the scope of using this structure. The article also discusses the issue of the identity of the legal rule, required by the act, the reference to which in the amended legal state became the rule which was the basis for the punishment, and not, as it was commonly previously believed, the rule stating the basis for punishing for each of the crimes remaining in the series. In the margin of the analysis of the new shape of the premises of series there are remarks devoted to the punishment for the multiplicity of crimes embraced with the feature of continuity.

Keywords: novelty, crime, series, coincidence, multiplicity, multi-act, qualification, identity, possibility, continuity.

${ }^{63}$ Ibidem, s. 666-667; P. Kardas [w:] System prawa..., s. 596 n. 